TIGG Vol.2 No.7 (1990)

MINIREVIEN (TIGG-09/02/90-MR-3)

\title{
Association of Ganglioside with the TSH Receptor
}

Wojciech KIELCZYNSKI, Peter J. LEEDMAN and Leonard C. HARRISON

Burnet Clinical Research Unit, The Walter and Eliza Hall Institute of Medical Research, PO Royal Melbourne Hospital, Victoria 3050, Australia

FAX: $61-3-347-0852$

Thyroid stimulating hormone (thyrotropin, TSH), a pituitary glycoprotein hormone, binds to receptors on thyroid follicular cell membranes. The TSH receptor (TSH-R) mediates the effect of TSH to stimulate thyroid hormone synthesis and release and thyroid growth (1), and is the target of polyclonal autoantibodies that mimic or inhibit these bioeffects of TSH in Graves' disease (2-4).

It was suggested, 15 years ago, that the TSH-R is a protein-glycolipid complex (5). The protein component was cloned recently from dog (6) and human $(7,8)$ cDNA libraries and found to belong to the GTP binding protein family of receptors. It has a molecular weight of $\sim 85 \mathrm{kD}$ (unglycosylated) and contains a 400 amino acid extracellular domain with 5 possible glycosylation sites, followed by $\sim 350$ amino acids including seven transmembrane domains and an 80 amino acid intracellular domain.

The first indication that gangliosides (sialic acid-containing glycolipids) may be involved in the binding of TSH to its receptor came from studies by Mullin et al. (5) in 1975 . They showed that gangliosides purified from bovine brain could inhibit the binding of TSH to solubilized bovine thyroid plasma membranes. The best inhibitor was GD1b, followed by GM2, GM3 and GM1. Inhibition was considered to result from interaction of ganglio- side with TSH itself rather than with TSH-R (5), based on gel chromatography experiments, fluorescence changes of the TSH molecule and ganglioside preincubation studies with TSH and receptor proteins. At that time, binding studies were performed in high salt

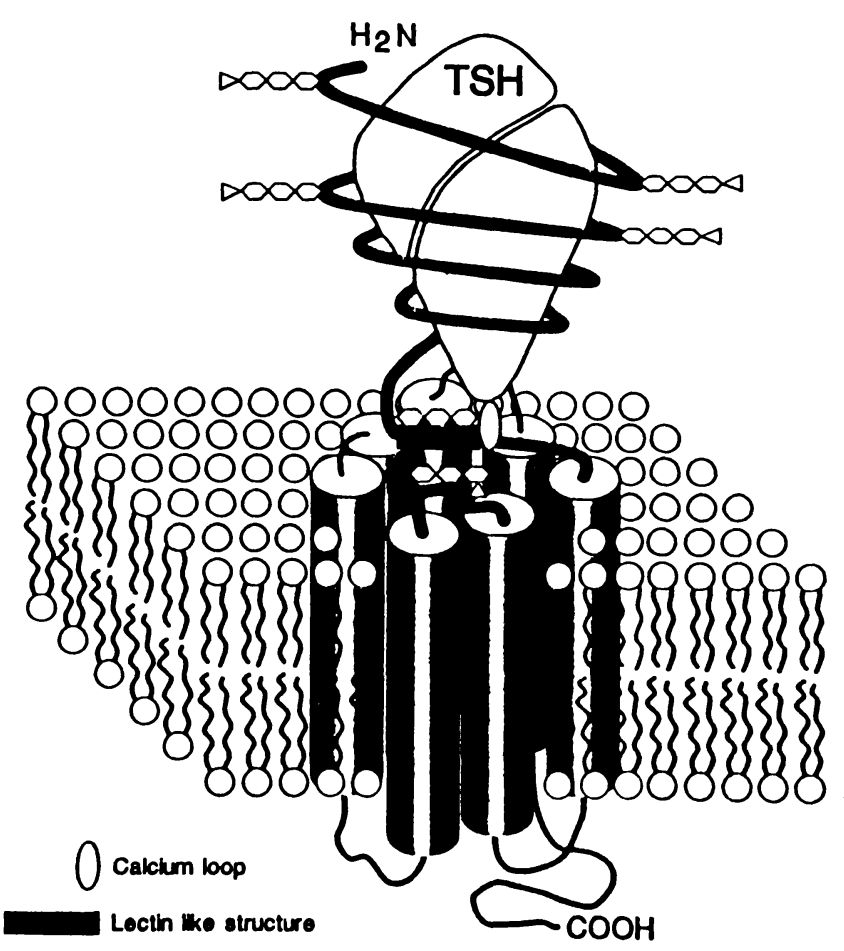

Fig. Model of the TSH receptor showing possible ganglioside binding sites. 


\section{ミニレピュ-(TIGG-09/02/90-MR-3) \\ ガングリオシドがしっかりと付いていろ T S IIレセブター}

W. KIELCZYNSKI, P. J. LEEDMAN, L. C. HARRISON

甲状腺刺激ホルモン（サイロトロピン、 TSH）は脸下垂体から分泌される糖タンパク質 ホルモンで、甲状腺の小萋細胞膜上のレセプ ターに結合する。TSHレセプター（以下TSH-R と略記）はTSHの作用を伝えて甲状腺ホルモン の合成と分泌および甲状腺の成長を促進する が(1)，一方Graves病ではTSHの生物効果を模做 したり阻害したりするポリクローンの自己抗 体の標的でもある(2-4)。

TSH-Rはタンパク質一糖脂質複合体であるこ とが、15年前に報告された(5)。タンパク質部 分は最近になってイヌ(6)およびヒト $(7,8) の$ CDNAライブラリーからクローニングされ、 GTP結合タンパク質レセプターファミリーに属 することが判った。分子量は搭鎖なしで約 $85 \mathrm{kD}$ であり、榶鎖の付き得る5个所の部位を含 む400アミノ酸から成る細胞外ドメイン、7所 の膜貫通ドメインを含む350ケのアミノ酸およ び80アミノ酸から成る細胞内ドメインから出 来ている。

TSHがTSH-Rに結合する時にガングリオシド （シアル酸を含む搭脂質）が関与しているの ではないかということは、1975年に Mullin らの研究により示された(5)。彼等は、ウシの 脳から精製したガングリオシドを加えると、 可溶化したゥシ甲状腺形質膜へのTSHの結合が
阻害されることを示した。最す強く阻害する のは GD1b であり、以下 GM2, GM3, GM1 の順 であった。ゲルクロマトグラフィ一実検、 TSH分子の蛍光变化、ガングリオシドをTSHと レセプタータンパク質と前処理する実銩に基 づいて、ガングリオシドによる阻害はガング リオシドがTSH-Rとではなく、TSH自身と反応 する為であると考えられた(5)。当時は、 $\mathrm{pH}$ 6.0 で高塩湌度の緩街液中で結合実呀が行な われたが、これは後に批判の対象となった。 同じ研究者達から GD1b よりもTSH結合を強力 に阻害するウシ甲状腺由来の新しいガングリ オシドについての報告がなされた(9)。このガ ングリオシドはウシ甲状腺ガングリオシドの $0.015 \%$ 含まれ、TLCブレート上では GM3 と同 じ移動度を示し、DEAE クロマトグラフィーに よるとシアル酸を 2 モル含んでいると判定さ れた。Vibrio cholerae シアリダーゼに感受 性がおって GD1b ガングリオシドと矛盾しな いが、これ以上の同定はされなかった。

TSH-Rにガングリオシドが存在することを支 持する別の報告がある。Gardas ら(10,11)は、 アルカリ分解のあとでもジシアロガングリオ シドが、弱まったとは言え、TSHの結合を阻害 することを見出した。TSHがガングリオシドを 含むりポソームに結合することや、TSHがガン 
buffers at $\mathrm{pH} 6.0$, conditions which later became the subject of criticism. Further report from the same investigators (9) described a novel bovine thyroid ganglioside which was a much more potent inhibitor of TSH binding than GD1b. This ganglioside constituted $0.015 \%$ of bovine thyroid gangliosides, migrated with GM3 on TLC plates and had two sialic acid molecules as detected by DEAE chromatography. It was sensitive to Vibrio cholerae sialidase treatment, consistent with GD1b ganglioside, but was never characterized further.

There are other reports consistent with the presence of ganglioside in the TSH-R. Thus, Gardas et al. $(10,11)$ found that even after alkaline degradation disialylated gangliosides can still inhibit the binding of TSH, although to a lesser extent. It has been shown also that TSH binds to liposomes containing gangliosides and that TSH alters the membrane conductance of lipid bilayers containing gangliosides $(12,13)$.

Kohn (14) has proposed a model of the TSH-R incorporating both protein and ganglioside components. According to this model, the $B$ subunit of TSH binds to the receptor protein causing a conformational change in hormone; the $\alpha$ subunit then penetrates the membrane and interacts with the ganglioside which mediates activation of adenylate. cyclase. The model was based on the action of Vibrio cholerae toxin, whose $B$ subunit binds to the ganglioside GM1 and $A$ subunit penetrates the membrane (15-17). It was not supported by others who found no inhibition of TSH binding by gangliosides (18-21) and either no effect $(22,23)$ or an increase $(18,24)$ of TSH binding after neuraminidase treatment of the receptor, leading to their categorical conclusion that gangliosides had no role in the binding to TSH to intact thyroid cells under physiological conditions (24).

The first monoclonal antibodies (MCAb) to the TSH-R described in 1981 by Yavin et al. (25) failed to stimulate adenylate cyclase and were not directed towards ganglioside molecules. Later, the same group (26) generated MCAb which reacted with thyroid gangliosides and inhibited TSH binding. However, the glycoprotein component of the TSH-R also appeared to react with these MCAb. It was concluded therefore that reactivity of the anti-ganglioside MCAb with receptor protein was due to the intimate association of TSH-R ganglioside and protein.

The first systematic analysis of bovine thyroid gangliosides was reported in 1982 by Iwamori et al. (27). There was a complex pattern of gangliosides containing $\mathrm{N}$-acetylneuraminic acid (NeuAc) or $\mathrm{N}$-glycolylneuraminic (NeuGc) acid, or both, in the case of polysialylated gangliosides. In order of abundance GM3 > GD1a > GM1 > FucGM1 $>$ GD3; GD1b was not detected. Subsequently, a detailed analysis of human thyroid gangliosides by Svennerholm (28) revealed that $\mathrm{GM} 3>\mathrm{GD} 3>\mathrm{DG} 1 \mathrm{a}>$ $3^{\prime} \mathrm{LM} 1>\mathrm{GD} 1 \mathrm{~b}>\mathrm{GT} 1 \mathrm{~b}>\mathrm{GQ1b}>\mathrm{GM} 1=$ $6^{\prime}$ LM1 = GD2 > $3^{\prime}$ LD1 > FucGM1, NeuAC was the only sialic acid present in human thyroid. He also reported the presence of $\mathrm{N}$-acetyl-9-0-acetylneuraminic acid in monosialogangliosides $(10 \%$ of total sialic acid) and traces of other Oacetylated sialic acids in GD1b, GT1b and GQ1b. Systematic analyses of rat thyroid gangliosides have not been reported, but gangliosides from a normal rat thyroid cell line (FRTL-5) (29) showed a much simpler pattern in TLC (W. Kielczynski et al. - unpublished). GM2 was the most prominent and migrated as a doublet, followed by GM3 (doublet) and GD1a. A rat thyroid tumor cell line insensitive to TSH was 
グリオシドを含む脂質二重層の膜誘電索を变 化させることも知られている $(12,13) 。$

Kohn はタンパク質とガングリオシドを両者 とす含むTSH-Rのモデルを提出している(14)。 このモデルによると、TSHの $\beta$ サブュニットは レセプタータンパク質に結合してホルモン分 子内にコンフォメーション变化を惹き起し、 その結果 $\alpha$ ーサブュニットは膜に貫入してガ ングリオシドと反応し、それがアデニルシク ラーゼを活性化すると言う。このモデルは、 Vibrio cholerae トキシンのBサブュニット がガングリオシド GM1 に結合してAサブュニ ットが膜を通過するというコレラ毒素の作用 機作(15-17)に基づいていた。しかし、TSHの 結合がガングリオシドにより阻害されない (18-21)とか、レセプターをノイラミニダーゼ 処理することでTSHの結合が影辢を受けない $(22.23)$ とか增加する $(18.24)$ という他の研究 者による研究により否定され、生理的条件下 ではTSHの結合にガングリオシドは全く関与し ていないという明確な結論が迸き出されたの である(24)。

1981年 Yavin らにより記載された最初の TSH-Rに対するモノクローン抗体（MCAb）はア デニルシクラーゼを活性化することはできず、 ガングリオシド分子には反応しなかった（25）。 後年、同じ研究グループは甲状腺ガングリオ シドと反応する MCAb を作製したが、これは TSH結合を阻害した（26）。しかし、TSH-Rの模 タンパク質成分もこの MCAb と反応するみた いだった。それで、この抗ガングリオシド MCAb とレセプタータンパク質との反応性は
TSH-Rガングリオシドとタンパク質が密接に関 わっているからであると考えられた。

ウシ甲状腺ガングリオシドの最初の組維的 な分析は1982年に岩森らにより行なわれた (27)。ポリシアリルガングリオシドの場合、 N-アセチルノイラミン酸（NeuAc）かN-グリコ リルノイラミン酸 (NeuGc) のどちらかか、或 いは両方を含んでいるという複雑なガングリ オシドのパターンであった。多い順に書くと、 $\mathrm{GM3}>\mathrm{GDla}>\mathrm{GM1}>\mathrm{FuCGM1}>\mathrm{GD3}$ で、GD1b は検出されなかった。引き続いて、 Svennerholm による詳しいヒト甲状腺ガング リオシドの分析が出され、それによると、 $\mathrm{GM} 3>\mathrm{GD} 3>\mathrm{GDla}>3^{\circ} \mathrm{LH} 1>\mathrm{GDlb}>\mathrm{GT1b}$ $>\mathrm{GQ}_{1 \mathrm{~b}}>\mathrm{GM}_{1}=6^{\circ} \mathrm{LM1}=\mathrm{GD2}>3^{\circ} \mathrm{LD} 1>\mathrm{Fuc}$ GM1 であった。ヒト甲状腺のシアル酸は NeuAc のみであった。彼はモノシアロガング リオシド（全シアル酸の10\%）中にはNーアセチ ルー9-0-アセチルノイラミン酸の存在すること、 GD1b，GT1b，GQ1b 中には他の0-アセチル化シ アル酸が微量に含まれていることも報告した。 ネズミ甲状腺ガングリオシドの体系的分析は まだなされていないが、正常ネズミ甲状腺細 胞株（FRTL-5）（29）のガングリオシドはTLCプ レート上ではもう少し策純なパターンである （W. Kielczynski ら、末発表）。GM2 が最も 多く、TLC上ではダブレットであり、次に多い のが GM3（ダブレット）とGDlaであった。 TSHに反応しないネズミの甲状腺腫第細胞株に は GM3 があるだけで、他のすべてのガングリ オシドが欠けていた $(30)$ 。しかし、TSHに反応 するネズミの妇状腺腫痨細胞株から抽出した 
devoid of gangliosides except GM3 (30). However, when incubated in gangliosides extracted from rat thyroid tumor cells which were sensitive to TSH, the cells exhibited TSH binding and stimulation of adenylate cyclase (31).

The most widely used methods for detecting gangliosides are resorcinol or thiobarbituric acid $(32,33)$, which can detect micrograms of glycolipids. Introduction of the overlay technique on TLC plates by Magnani (34) facilitated detection of nanograms of gangliosides of defined structure, by monoclonal antibodies (35), cells (36) or cholera toxin (37). To further improve the sensitivity of detection of all gangliosides we employed the 125Ilabelled, sialic acid-specific lectin, Limax flavus agglutinin (LFA), as a probe to screen crude glycolipid extracts for sialic acid containing components (38). LFA has a molecular weight of 44,000 and consists of two equal-sized subunits, does not display an absolute requirement for $\mathrm{Ca} 2+$ and is easily labelled and stable for 3 weeks after iodination at a specific activity of less than $35 \mu \mathrm{Ci} / \mu \mathrm{g}$. LFA probing was used for the preliminary characterization of gangliosides associated with the purified human TSH-R. TSH-R was obtained from human thyroids by solubi- lization in Triton $\mathrm{X}-100$ and sequential affinity chromatography on wheat germ agglutinin (Triticum vulgaris) and TSH columns $(39,40)$. A $50 \mathrm{kD}$ protein was eluted in $3 \mathrm{M} \mathrm{NaCl}$, which bound TSH as well as immunoglobulins from patients with autoimmune thyroid disease. Glycolipids were extracted by Folch partition from purified receptor eluted from TSH affinity colum (41) and were sensitive to ceramide glycanase digestion. This enzyme cleaves bonds between the ceramide moiety and glucose $(42,43)$.

The ganglioside co-purified with human TSH-R migrated between GM1 and GD3 on TLC. It was not sensitive to Vibrio cholerae sialidase but was sensitive to Arthrobacter ureafaciens sialidase ( $W$. Kielczynski et al. submitted) which implies that it belongs to the GM1 family of gangliosides. This family, taking into consideration the carbohydrate moiety only, includes GM1, GM1b, FucGM1, LM1 (lacto-series ganglioside), O-acylated gangliosides $(4,7,8,9-0$-acetylated - from each of the above groups) as well as O-methylated and sulphated gangliosides. Additionally, sialic acid can be linked via $2 \rightarrow 3$ or $2 \rightarrow 6$ bonds to galactose and possibly to galactosamine (44). Because the exact

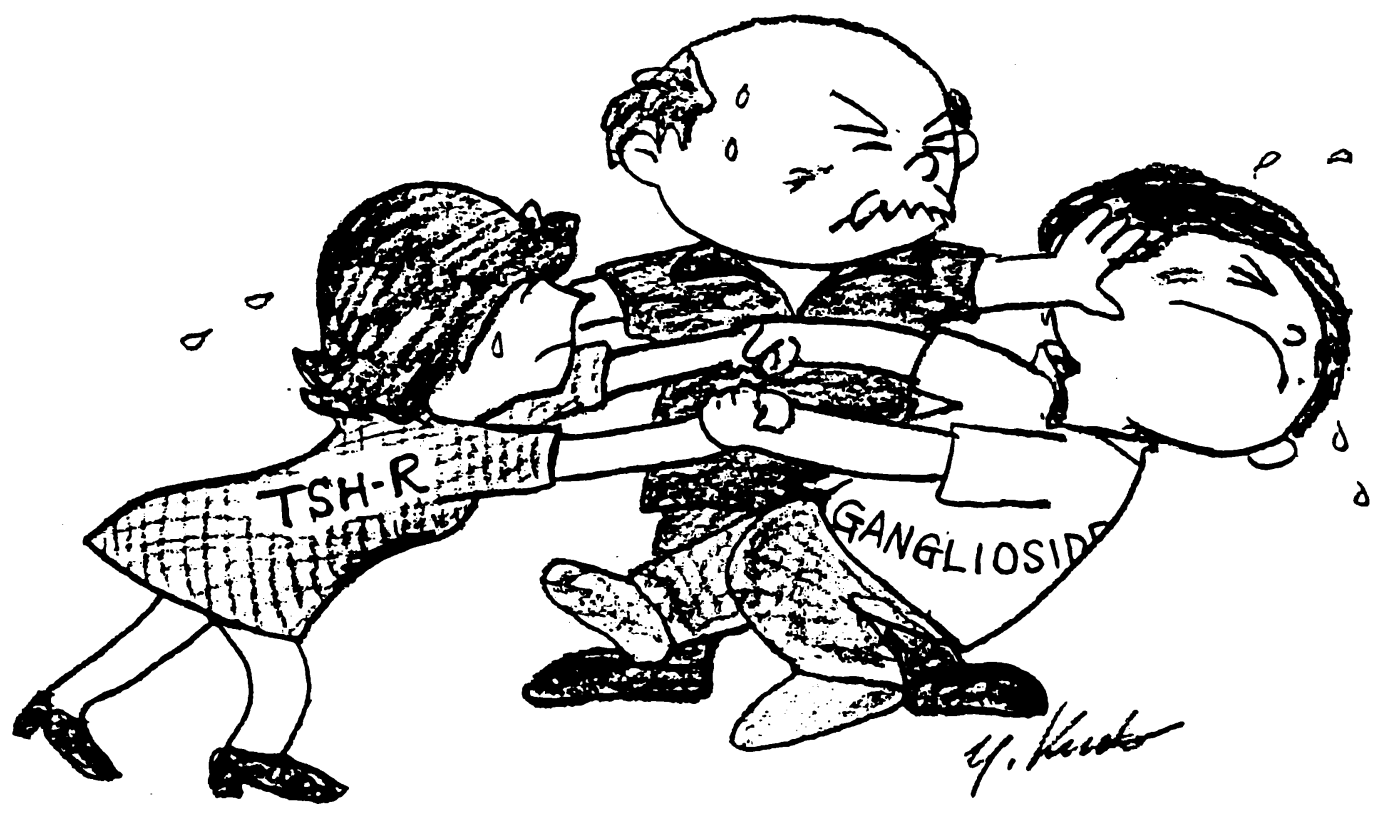


ガングリオシドを加えてインキュベートする と、この細胞はTSH結合を示しアデニルシクラ 一ゼの活性化が起こった(31)。

ガングリオシドの検出に最も広く用いられ ている方法はレソルシノール法とチオパルビ ッール酸法 (32,33)であり、この方法でマイク ログラムの楉脂質が検出できる。Magnani ら （34）によるモノクローン抗体 (35)、細胞 (36) やコレラ毒素(37)を用いるTLCプレートの重層 法により、特定の構造を持つガングリオシド はナノグラムレベルでの検出が容易になった。 私達はすべてのガングリオシドの検出感度を 更に上げるために、 ${ }^{125} \mathrm{I}$-標識のシアル酸特異 的レクチン、 Limax $\mathrm{flavus}$ アグルチニン

（LFA）をシアル酸を含むガングリオシド粗抽 出液のスクリーニングのプローブとして用い ることにした(38)。LFA の分子量は44,000で 等しい大きさの 2 ケのサブュニットから成り、 $\mathrm{Ca}^{2+}$ を絶対的に要求することはなく、ヨード て $35 \mu \mathrm{Ci} / \mu \mathrm{g}$ の比放射能まで標識すること が容易であり、これは 3 週間は安定に用いる ことができる。精製したヒトTSH-Rに含まれる ガングリオシドの第一次同定のために LFA プ ローブ法を用いてみた。TSH-Rはヒト甲状腺か らトリトン X-100 の可溶化と、小麦胚アグル チニン（Triticum vulgaris の MGA）および TSHのアフィニティカラムクロマトグラフィー で得られたものである(39,40)。50kD のタン パク質が $3 \mathrm{M} \mathrm{NaCl}$ で溶出されたが、これは TSHならびに自己免疫疾患甲状腺病の患者の免 疫グロブリンに結合した。TSHアフィニティカ ラムで精製したレセプター(41)から Folch 分
眍により桔脂質を抽出したが、これらはセラ ミドグリカナーゼ(42)、エンドグリコセラミ ダーゼ(43)で分解できた。これらの醉秦は粘 脂質のオリゴ桔とセラミドの間のグリコシド 結合を開裂する。

ヒトTSH-Rと一緒に精製されたガングリオシ ドはTLC上で GM1 と GD3 の間に移動した。こ のガングリオシドは Vibrio cholerae シアリ ダーゼには感受性がなく Arthrobacter ureafaciens シアリダーゼで分解されたが、 これはこのガングリオシドが GM1 系列に属す ることを意味している（W. Kielczynski ら、 投稿中）。㮴部分だけを考虑に入れているわ けであるが、この系列には GM1，GM1b、Fuc GM1，LM1（ラクト系列ガングリオシド）、0アセチル化ガングリオシド（上記の各ガング リオシドのそれぞれ 4,7,8,9-0-アセチル体）、 これらの0ーメチル化体、硫酸化体が含まれる。 更に、シアル酸は 2-3 又は 2-6 でガラクト ースに、そしてガラクトサミンに結合してい ることもおる(44)。このTSH-Rの正確なガング リオシドの棒造は不明なので、糖鎖楆造のみ 推即するしかない。フコースの付いた GM1 が ウシ $(27)$ とヒト $(10,32)$ の状腺から0ーアセ チルガングリオシド(32)のような微量ガング リオシドとして見出されているのは間味深い。 ヒトのTSH-Rガングリオシドはポリシアルガン グリオシドのラクトンである可能性むおるが、 これは LFA で検出できる（W. Kielczynski， 末発表）。ガングリオシドの末精製品は、微 底的に純化したガングリオシド標品よりるう クトンを含むことが多い。ウシ GD1b はTSH結 
structure of this TSH-R ganglioside is not known we can only speculate about its carbohydrate composition. It is of interest that fucosylated GM1 was described in bovine (27) and human $(10,32)$ thyroids as a minor ganglioside, as were O-acetylated gangliosides (32). The human TSH-R ganglioside could also be a lactone of a polysialylated ganglioside, which can be detected by LFA ( $W$. Kielczynski - unpublished). Crude ganglioside preparations are more likely to contain labile lactones than those obtained after extensive purification. GD1b was originally found to be the strongest bovine ganglioside inhibitor of $\mathrm{TSH}$ binding (5), and. GD1b lactone migrates below GM1 (45). Ganglioside lactones have been shown to occur naturally in the nervous system of rodents (46) and in human brain (45). GD1b lactone would also be Vibrio cholerae sialidase resistant due to its blocked carboxyl group vicinal to the $\alpha$-ketosidic linkage, but in contrast to our finding with the purified TSH-R ganglioside, it should be resistant to Arthrobacter ureafaciens sialidase (45).

The fact that gangliosides can be strongly bound to protein by covalent (47) or non-covalent $(48,49)$ interactions is well documented, but the exact sites of interaction are unknown. We have analyzed the recently published sequence of the dog TSH-R to deduce $a$ possible site for its interaction with ganglioside. In the extracellular domain, close to the first transmembrane domain, there is a 52 amino acid sequence specific for the TSH-R not present in other glycoprotein hormone receptors $(6)$. In this sequence there is an 11 amino acid stretch with $80 \%$ homology to the sequence of Arachis hypogea (peanut) lectin. This lectin only binds GM1 (49). On the other hand, similar sequences are found in calcium binding proteins and calcium binding and carbohydrate binding are usually to different sites in proteins (49). We therefore searched for another sequence which might interact with ganglioside, based on a knowledge of cholera toxin binding to gangliosides. Cholera toxin binding to ganglioside induces a "shift" in the fluorescence emission spectrum of the protein (5) and because chemical modification of tryptophan residues abolishes cholera toxin binding to ganglioside (50) it has been suggested that tryptophan is crucial in the interaction. There are only two tryptophan residues in the extracellular sequence of the TSH-R. One, position 238, is not present in other glycoprotein hormone receptors (6); the other is highly conserved and is placed on a loop between the second and the third transmembrane domains only 5 amino acids from cell membrane. This 21 amino acid loop is also rich in residues which have been implicated in cholera toxin-ganglioside binding (50), ie tyrosine (3), histidine (2), asparagine and aspartic acid (3) and glutamine and glutamic acid (2) .

our direct demonstration of the intimate association of a specific ganglioside with the TSH-R glycoprotein implies a critical role for this ganglioside in TSH-R structure and function, as suggested previously. The availability of cloned TSH-R and techniques for identifying and analyzing the ganglioside should enable questions about the nature of its interactions and its role to be answered.

\section{References}

1. Field, J.B. (1986) In: Werner's The Thyroid eds. Ingbar, S.H. and Braverman, L.E. (J.B. Lippincott, Philadelphia), pp 288-304.

2. Ress-Smith, B., McLachlan, S.M. 
合を最も強く阻害するガングリオシドとして 初めて記載されたが(5)、この GD1b ラクトン は TLC で GM1 の下に移動する(45)。天然に は、このラクトン化されたガングリオシドは 契類の神経系 (46) とヒト脳 (45)で見出され ている。GD1b ラクトンは $\alpha$ ーケト基の隣のカ ルボキシル基が塞がっている為に Vibrio cholerae シアリダーゼに抵抗性があると思わ れるが、精製したTSH-Rガングリオシドで私達 が見出したことに反して、Arthrobacter ureafaciens シアリダーゼ(45)にも抵抗性が おる筈である。

ガングリオシドが共有結合で(47)あるいは 非共有結合で $(48.49)$ タンパク質にしっかりと 結びついていることは良く理解されているが、 正確な相互作用の場は判っていない。ガング リオシドと反応し得る場所を推測するために、 最近報告されたイヌのTSH一Rの列を解析して 見た。最初の膜貫通ドメインに近い細胞外ド メインの中に、他の榶タンパク質ホルモンレ セプター（6）には決して見られない52 アミノ 酸から成るTSH-Rに特異的な配列がある。この 配列の中の11ケのアミノ酸列列は Arachis hypogea (ピーナツ) レクチンの挋列と $80 \%$ のホモロジーがある。このレクチンは GM1 に のみ結合する(49)。一方、類似の眍列がカル シウム結合タンパクでも見付かっているが、 カルシウム結合と搪結合とはタンパク質の中 では別々の部位であるのが普通である(49)。 従って、ガングリオシドに結合するコレラ毒 索における知識に基づいて、ガングリオシド と結合するかも知れない別の卧列を挆してみ
た。コレラ毒菜はガングリオシドに結合する とタンパク質の緟光放射スペクトルに「変位」 が生じるし(5)、トリプトファン残基を化学修 飾するとコレラ毒菜のガングリオシドに対す る結合能が失われるので(50)、トリプトフォ ンがこの相互作用で決定的に重要であると思 われた。TSH-Rの細胞外ドメイン列にはたっ た 2 個のトリプトファン残基しかない。その

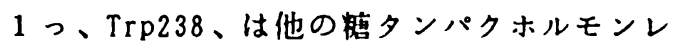
セプターには見出されず(6)、もう1っは他の レセプター同様よく保存されていて、細胞膜 からアミノ酸 5 個分離れて第 2 抢よび第 3 の 膜貫通ドメインの間のループに存在している。 この21個のアミノ酸から成るループは、コレ ラ毒卖でガングリオシド結合に関与している と思われる部位 $(50)$ に多いアミノ酸、つまり、 チロシン(3)、ヒスチジン(2)、アルパラギン およびアスパラギン酸(3)、グルタミンとグル タミン酸(2)、を多く含んでいる。

TSH-R榶タンパク質と特別なガングリオシド が密接な関係にあるという私達の直接的な証 拠は、以前言われたように、ガングリオシド がTSH-Rの構造と機能に於て決定的役割を果た していることを暗示する。クローニングされ たTSH-Rが使えるようになったし、ガングリオ シドを分析し同定する技術も進んだので、こ の相互作用の本態や役割についての疑問に答 えらるようになるだろう。

三菱化成生命科学研究所 - 被合惦質研究室 山形達也 訳 
and Furmaniak, J. (1988) Endocrine Rev. 9, 106-120.

3. Drexhage, H.A., Bottazzo, G.F. and Doniach, D. (1983) In: Cytochemical Bioassays, Techniques and Clinical Applications eds. Chayen, J. and Bitensky, L. (Marcel Dekker, New York), pp 153-172.

4. Zakarija, M. and McKenzie, J.M. (1980) Endocrinology 107, 20512054.

5. Mullin, B.R., Fishman, P.H., Lee, G., Aloj, S.M., Ledley, F.D., Winand, R.J., Kohn, L.D. and Brady, R.O. (1976) Proc. Natl. Acad. Sci. USA 73, 842-846.

6. Permantier, M., Libert, F., Meanhaut, C., Lefort, A., Gerard, C., Perret, J., Van Sande, J., Dumont, J.E. and Vassart, G. (1989) Science 246, 1620-1622.

7. Nagayama, Y., Kaufman, K.D., Seto, P. and Rapoport, B. (1989) Biochem. Biophys. Res. Commun. 165, 1184-1190.

8. Misrahi, M., Loosfelt, H., Atger, M., Sar, S., Guiochon-Mantel, A., and Milgrom, E. (1990) Biochem. Biophys. Res. Commun. 166, 394403.

9. Mullin, B.R., Pacuszka, T., Lee, G., Kohn, L.D., Brady, R.O. and Fishman, P.H. (1978) Science 199, 77-79.

10. Gardas, A. and Nauman, J. (1981) Acta Endocrinol. (Copenh) 98, 549-555.

11. Gardas, A., Adler, G., Lewartowska, A., Faryna, M. and Nauman, J. (1983) Acta Endocrinol. (Copenh) 104, 333-339.

12. Aloj, S.M., Lee, G., Grollman, E.F., Beguinot, F., Consiglio, E. and Kohn L.D. (1979) J. Biol. Chem. 254, 9040-9049.

13. Poss, A., Deleers, M. and Ruysschaert, L.M. (1978) FEBS
Lett. 86, 160-162.

14. Kohn, L.D. (1978) In: Receptors and Recognition eds. Cuatrecasas, P. and Greaves, M.F. (Chapman and Hall, London) Ser. A, Vol. 5, pp. 135-211.

15. Moss, J., Fishman, P.H., Richards, R.L., Alving, C.R., Vaughan, M. and Brady, R.O. (1976) Proc. Nat. Acad. Sci. USA 73, 3480-3483.

16. Moss, J., Richards, R.L., Alving, C.R. and Fishman, P.H. (1977) J. Biol. Chem. 252, 797-798.

17. Ludwig, D.S., Ribi, H.O., Schoolnik, G.K. and Kornberg, R.D. (1986) Proc. Natl. Acad. Sci. USA 83, 8585-8588.

18. Pekonen, F. (1980) Horm. Metab. Res. 12, 310-314.

19. Powell-Jones, C.H.J., Thomas, C.G. and Nayfey, S.N. (1980) J. Biol. Chem. 255, 4001-4010.

20. Friedman, Y., Hladis, P., Babiarz-Crowell, D. and Burke, G. (1979) Endocr. Res. Commun. 6, 71-92.

21. Holmes, G.D., Titus, G., Chou, M. and Field, J.B. (1980) Endocrinology 107, 2076-2081.

22. Moore, W.V. and Feldman, L. (1976) J. Biol. Chem. 251, 42474253.

23. Amir, S.M., Goldfine, I.D. and Ingbar, S.H. (1976) J. Biol. Chem. 251, 4693-4699.

24. Beckner, S.K., Brady, R.O. and Fishman, P.H. (2981) Proc. Natl. Acad. Sci. USA 78, 4848-4852.

25. Yavin, E., Yavin, Z., Schneider, M.D. and Kohn, L.D. (1981) Proc. Natl. Acad. Sci. USA 78, 31803184 .

26. Valente, W.A., Vitti, P., Yavin, Z., Yavin, E., Rotella, C.M., Grollman, E.F., Toccafondi, R.S. and Kohn, L.D. (1982) Proc. Natl. Acad. Sci. USA 79, 6680-6684. 
27. Iwamori, M., Sawada, K., Hara, Y., Nishio, M., Fujisawa, T., Imura, H. and Nagai, Y. (1982) J. Biochem. 91, 1875-1887.

28. Svennerholm, L. (1985) Biochim. Biophys. Acta 835, 231-235.

29. Ambesi-Impiambato, F.S., Parks, L.A.M. and Coon, H.G. (1980) Proc. Natl. Acad. Sci. USA 77. 3455-3459.

30. Meldolesi, M.F., Fishman, P.H., Aloj, S.M., Kohn, L.D. and Brady, R.O. (1976) Proc. Natl. Acad. Sci. USA 73, 4060-4064.

31. Lacceti, P., Grollman, E.F., Aloj, S.M. and Kohn, L.D. (1983) Biochem. Biophys. Res. Commun. 110, 772-778.

32. Svennerholm, L. (1957) Biochim. Biophys. Acta 24, 604-611.

33. Aminoff, D. (1961) Biochem. J. 81, 384-392.

34. Magnani, J.L., Smith, D.F. and Ginsburg, V. (1980) Anal. Biochem. 109, 399-402.

35. Brockhaus, M., Magnani, J.L., Blaszczyk, M., Steplewski, Z., Koprowski, H., Karlsson, K.A., Larsson, $G$ and Ginsburg, $V$. (1981) J. Biol. Chem. 256, 1322313225.

36. Hansson, G.C., Karlsson, K.A., Larsson, G., Stromberg, N. and Thurin, J. (1985) Anal. Biochem. 146, 158-163.

37. Fishman, P.H. (1986) Chem. Phys. Lipids 42, 137-151.

38. Kielczynski, W. and Harrison, L.C. (1990) Glycoconjugate J. 7, 75-84 .

39. Leedman, P.J., Newman, J.D. and Harrison, L.C. (1989) J. Clin. Endocrinol. Metab. 69, 134-141.

40. Leedman, P.J. and Harrison, L.C. (1990) In: Receptor Purification, ed. Litwack, G. (Humana Press, Philadelphia), (in press).

41. Kielczynski, W., Leedman, P.J. and Harrison, L.C. (1989) Proceedings of the Xth International Symposium on Glycoconjugates, Jerusalem, Israel, No 258; p 370.

42. Li, S.-C., DeGasperi, R., Muldrey, J.E. and Li, Y.-T. (1986) Biochem. Biophys. Res. Commun. 141, 346-352.

43. Ito, M. and Yamagata, T. (1989) J. Biol. Chem. 264, 9510-9519.

44. Schauer, R. (1982) Adv. Carbohydr. Chem. Biochem. 40, 131-234.

45. Riboni, L., Sonnino, S., Acquotti, D., Malesci, A., Ghidoni, R., Egge, H., Mingrino, S. and Tettamanti, G. (1986) J. Biol. Chem. 261, 8514-8519.

46. Gross, S.K., Williams, M.A. and McCluer, R.H. (1980) J. Neurochem. 34, 1351-1361.

47. Ji, T.H. (1974) J. Biol. Chem. 249, 7841-7847.

48. Sharom, F.J. and Grant, C.M.W. (1978) Biochim. Biophys. Acta 507, 280-293.

49. Chersh, D.A., Pytela, R. Pirschbacher, M.D., Klier, F.G., Ruoslahti, E. and Raisfeld, R.A. (1987) J. Cell Biol. 105, 11631173.

49. Goldstein, I.J. and Poretz, R.D. (1986) In: The Lectins, eds. Liener, I.E., Sharon, N. and Goldstein, I.J. (Academic Press, Inc., Orlando, FL), pp. 35-247.

50. De Wolf, M., Bastiaens, G., Lagrou, A., Van Dessel, G., Hilderson, H. and Dierich, W. (1987) In: Membrane receptors, dynamics and energetics, ed. Wirtz, K.W.A. (Plenum Press, New York, NY) NATO ASI Series A, Life Sciences, Vol. 133, pp 149-159. 